\section{Uetterrettelig om legemiddelindustrien}

I en artikkel av Robin Holtedahl med tilhørende leder av Lars Slørdal i Tidsskriftet nr. 10/2010 fremkommer en rekke uriktige påstander om Pfizer $(1,2)$.

For det første, Pfizer anbefaler ikke bruk av pregabalin ved fibromyalgi innenfor EU eller EØS, fordi dette ikke er godkjent indikasjon i disse landene.

Pfizer utfører sin kliniske forskning i henhold til de høyeste etiske og vitenskapelige standarder, og involverer uavhengige eksperter for å sikre at resultatene av våre studier er vitenskapelig robuste, objektive og pålitelige. Pfizer offentliggjør resultatene av alle studier som er fullført etter 1.10. 2002 i Clinical Study Results Database (3), etter de samme kriteriene som nevnt over, uavhengig av utfall eller hvor studien er utført.

Holtedahl påstår at det finnes seks randomiserte studier der man undersøker virkningen av pregabalin ved fibromyalgi, hvorav kun tre er publisert. Det finnes faktisk bare fem. Fire av disse er publisert som originalartikler ((4), samt Holtedahls referanser 14, 23 og 24) mens den femte er presentert som en poster (Holtedahls referanse 25), og ble sendt inn til et fagfellevurdert tidsskrift i mai 2010. I alle studiene er konklusjonen basert på det primære endepunktet. Holtedahl hevder også at det ikke foreligger tilgjengelige data fra A0081056, men studien er publisert og fremkommer $\mathrm{i}$ hans litteraturliste som nr. 23. Videre hevder Holtedahl at sekundære endepunkter bare ble «fullstendig rapportert» $i$ to studier. De sekundære endepunkter for studien A0081100 er imidlertid publisert (5).

Uavhengige organisasjoner som European League Against Rheumatism (EULAR) og Cochrane Collaboration har vurdert alle tilgjengelige data i sine anbefalinger. EULAR ga sin sterkeste anbefaling til et sett farmakologiske behandlinger, inkludert pregabalin (Holtedahls referanse 28). Cochrane Collaboration konkluderte i sin gjennomgang at pregabalin hadde dokumentert effekt på nevropatiske smertetilstander og fibromyalgi (Holtedahls referanse 10).

Holtedahl feiltolker videre en artikkel i Tidsskriftet angående pregabalin og misbrukspotensial (Holtedahls referanse 9). I denne artikkelen ble det påpekt at pregabalin har mindre potensial for avhengighet og misbruk enn alkohol og benzodiazepiner, og at den påviste økning i bruk ikke nødvendigvis indikerer misbruk. Pregabalins preparatomtale vil bli oppdatert i nærmeste fremtid, etter at enighet er oppnådd mellom europeiske legemiddelmyndigheter (EMEA/CHMP) og Pfizer, med henblikk på misbrukspotensialet for pregabalin og i hvilken spesifikk populasjon dette kan observeres (6).

Til slutt diskuterer Holtedahl markeds- føringen av pregabalin ved fibromyalgi, men han tar ikke høyde for at preparatet er godkjent for andre indikasjoner i USA. Pfizer har etter amerikansk lovgivning anledning til å kommunisere direkte med leger og forbrukere i USA, også på amerikanske nettsteder. Denne kommunikasjonen og annonseringen er kun ment for forbrukere i USA.

Pfizer ønsker en sunn debatt om helsevesenet og respekterer Holtedahls og Slørdals rett til å uttrykke sine personlige meninger. Samtidig verdsetter Pfizer muligheten til å levere et kunnskapsbasert svar på alvorlige påstander fremsatt av forfatterne $(1,2)$.

\section{Yngve Mikkelsen}

Pfizer Norge

\section{Litteratur}

1. Holtedahl R. Tvilsom dokumentasjon av effekten av pregabalin ved fibromyalgi. Tidsskr Nor Legeforen 2010: 130: 1032-6.

2. Slørdal L. Kan vi stole på legemiddelindustrien? Tidsskr Nor Legeforen 2010; 130: 1013.

3. ClinicalStudyResults.org www. clinicalstudyresults.org (14.6.2010)

4. Crofford LJ, Mease PJ, Simpson SL et al. Fibromy algia relapse evaluation and efficacy for durability of meaningful relief (FREEDOM): a 6-month, double-blind, placebo-controlled trial with pregabalin. Pain 2008; 136: 419-31.

5. U.S. National Institutes of Health. Clinical Trials.gov. www.clinicaltrials.gov/ct2/show/ results/NCT00333866?term=A0081100\&rank $=2 \&$ sect $=X 8$ i015\# outcome3 (14.6.2010).

6. European Medicines Agency. Refusal European Public Assessment Report (Refusal EPAR), Lyrica (pregabalin). www.ema.europa.eu 3.11. 2009 (14.6.2010).

\section{R. Holtedahl svarer:}

Pfizer har rett $i$ at de to studiene A0081056 og A0081077 er blitt publisert (artikkelens referanser 23 og 24). Jeg ble oppmerksom på dette i april, og sendte inn revidert manus til redaksjonen, men dessverre for sent med hensyn til trykking. Manglende kryssreferanser mellom publiserte studier og studieregistrenes protokollnummer vanskeligjør oppsporing av slike koblinger. Vi kan enes om at det foreligger tre publiserte og én ufullstendig publisert studie av pregabalin ved fibromyalgi. Gjennomsnittlig prosentvis bedring på primære endepunkter på optimal dosering i de fire studiene var (etter mine beregninger) $13,4,14,9,9,3$ og 8,1 . Pfizer hevder at effekter på sekundære endepunkter i studie A0081100 er blitt publisert. Så vidt jeg kan se, er det imidlertid kun for det primære endepunkt (VAS) at det er oppgitt baselineverdier ved studiestart, og derved kan prosentvis klinisk bedring på øvrige endepunkter ikke beregnes. Croffords 2008-studie ble utelatt fordi den ikke hadde klassisk randomisert design. Hovedkonklusjonene i min analyse av de tre fullt publiserte studier (beskjedne og sprikende kliniske effekter, selektiv og lite balansert resultatrapportering) står etter mitt skjønn fortsatt ved lag. Monica Kjekens påstand om en «åpen og regulert pro- sess» er etter mitt skjønn lite forenlig med at to av de fire studiene unnlater å gi informasjon om effekter på alle endepunkter. At Cochrane-rapporten i sammendraget er forholdsvis positiv til pregabalin, må ses i sammenheng med at den tar for seg effekten også på postherpetisk nevralgi og diabetisk nevropati. Når man går nærmere inn på effekten på fibromyalgi alene, er tallene mindre overbevisende. Man vil altså måtte behandle ca. ti fibromyalgipasienter for at én skal oppnå $50 \%$ smertelindring.

Ifølge Trond Methi består legemiddelindustrien av enkeltmennesker, som ikke har som motiv å «systematisk svindle, korrumpere og lyve» om sin forskning. Frigitte interne dokumenter i forbindelse med den føderale etterforskning av gabapentinskandalene i USA viser imidlertid hvordan det utover på 1990-tallet utviklet seg en korrumperende organisasjonskultur, der brudd på både forskningsetikk og retningslinjer for markedsføring mer var regelen enn unntaket. Det dreide seg om en systemisk og ledelsesstyrt praksis, som gjennomsyret alle organisasjonsnivåer. Negative forskningsresultater ble enten forsøkt forsinket, publisert i obskur eller vanskelig tilgjengelig form, eller rett og slett «glemt» (eksempel fra internt notat: «Vi bør være forsiktige med å publisere noe som kan ødelegge Neurontins markedssuksess») (1). Firmaet forsøkte også å påvirke Cochrane-utvalget som evaluerte gabapentin. I åtte av 12 publiserte gabapentinstudier ble det primære endepunkt endret underveis (2). Da salget av gabapentin sviktet i 2005, ble firmaets overordnede mål å øke salget av pregabalin på ikke-godkjente indikasjoner. Gjennom å fremsette falske påstander om pregabalins relative fortrinn, bestikkelse av opinionsledere osv. ble målsettingen overoppfylt. Pfizer lyktes også å få pregabalin på refusjonslisten (3). Selv om slike forhold ikke nødvendigvis kan ekstrapoleres til firmaets virksomhet i Norge, mener jeg, i motsetning til Kjeken, at "påstander om at industriens forskning er skjevvinklet (biased), konstruert og upålitelig» ikke er helt uten grunnlag.

\section{Robin Holtedahl}

Sykehuset Buskerud

Drammen

\section{Litteratur}

1. Dickersin K. Reporting and other biases in studies of Neurontin for migraine, psychiatric/bipolar disorders, nociceptive pain, and neuropathic pain. www.pharmalot.com/wp-content/uploads/2008/ 10/neurontin-dickersin-2.pdf (11.6.2010)

2. Vedula SS, Bero L, Scherer RW et al. Outcome reporting in industry-sponsored trials of gabapentin for off-label use. N Engl J Med 2009; 361: 1963-71.

3. United States District Court District of Massachusetts Civil Action No. 07-10304. http://i.bnet.com/ blogs/farber.pdf (11.6.2010). 